\title{
Music as a Possible Aspect of Pre-Evangelization
} Karel Ochozka

In the presented contribution the author views music as a possible form of pre-evangelization. The term music is - with respect to the text's orientation - used in a broader sense. It concerns so-called religious, spiritual music (i.e., music inspired by religion - the Bible, reverence for God and the saints, liturgy, life of the Church) and not merely liturgical, sacral or church music. In context with the topic, emphasis is placed primarily on the use of music in listening activities. The aesthetic element in music, which may contribute to music perception and use, is further pointed out. The topic is set in the context of Church documents and corresponds to the perception and function of music in the Church.

Due to the possibilities and extent of the paper, topics that could further develop the issue and describe it in more detail are not introduced (e.g. the negative influence of music, relationship of music and Church in historical context, active music making, etc.). The important and broad issue of liturgical music, setting psalms to music and psalm singing etc., is also left unelaborated. Application to specific practical examples would be interesting.

\section{Music}

Music and singing have accompanied humanity since its beginning. There are theories which claim that humans had mastered singing and singing expression far earlier than they started speaking. ${ }^{1}$ Singing and music are phenomena found wherever there are humans. They play an irreplaceable part in the life of humans and accompany them from childhood till life's end. ${ }^{2}$

Although every individual can use the term music to signify something else, musicology uses the term in contemporary conception to signify an organized system of sounds. The manner in which these sounds are selected, their rhythmical segmentation and arrangement, determines the quality, function and aesthetic effect ${ }^{3}$ of music. ${ }^{4}$ Based on the historical development of the concept of music and on how music is defined at present, we can suggest three spheres expressed by music. Music is an art which derives from human emotions and at the same time affects them. Music is conceived in connection with community, it has a social dimension. Music carries a spiritual idea and as such has a spiritual dimension. "Music contains two elements: acoustic material and a spiritual idea. The two do not stand as form and content in isolation side by side, but are joined in music in an integrated form (...). Since music is realized by sound, the most appropriate interpretation of music is sounding interpretation. The sensual

\footnotetext{
1 Charles Darwin believed that singing was the first means of communication which preceded language. He pointed out the similar function of birds' singing. More recently this theory was developed e.g. by the composer Olivier Messiaen.

2 Even before a child learns to express itself verbally, it communicates its feelings by means of its "vocal capacity".

3 Cf. Centrum hudební lexikografie, Český hudební slovník osob a institucí (on-line), at: http://www.ceskyhudebnislovnik.cz/slovnik/ index.php?option=com_mdictionary\&action=list_letter\&letter=h\#idxhu, accessed August 23, 2014.

4 The term music and its understanding varied in the course of history, it proceeds from the ancient mathematical-aesthetic-philosophical conception through the ethical-educational function up to the contemporary conception. For more see e.g. Jaroslav SMOLKA, Dějiny hudby, Brno: TOGGA, 2001.

5 Cf. Miloš SCHNIERER, unpublished lectures on musical aesthetics, Č. Budějovice: Konzervatoř, 1999.
} 


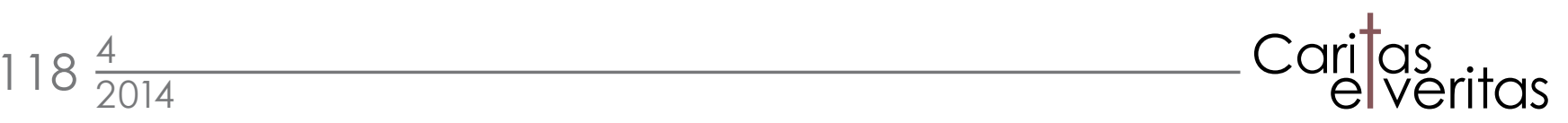

and spiritual experience of music is intensified by a combination of emotions, phantasy and the power of experience." 6

Not only can music in itself contribute to deeper knowledge of human beings, it is also an important means of the self-reflection of human existence in the world. Music can be a certain means of expression in relation to transcendence. Just as verbal speech is capable of stating and expressing a rationally understandable content, so music can state and offer rationally ungraspable, even unspeakable realities. With some overstatement we can say that where words end, singing and musical expression begin. Music and singing, besides a number of other functions, ${ }^{7}$ also occupy a special place in human dialogue with God. ${ }^{8}$ Since its beginnings, music was set in relation to religion. Yet music thus conceived need not be religious music (in a narrower sense). Like religion, music also strives to approach the unspeakable: without words, yet by a different language, the language of sounds. ${ }^{9}$ Music also serves to express non-sensual, psychological and spiritual contexts. "Where a human being meets God, there the mere language of words is not enough. Those spheres of her existence which themselves become singing are awakened." 10 The constitution Gaudium et spes suggests the important and noble mission of music. "Furthermore, when man gives himself to the various disciplines of philosophy, history and of mathematical and natural science, and when he cultivates the arts, he can do very much to elevate the human family to a more sublime understanding of truth, goodness, and beauty, and to the formation of considered opinions which have universal value. Thus mankind may be more clearly enlightened by that marvellous Wisdom which was with God from all eternity, composing all things with him, rejoicing in the earth, delighting in the sons of men. In this way, the human spirit, being less subjected to material things, can be more easily drawn to the worship and contemplation of the Creator."11

Thanks to various forms of art, it is possible to transform that which in itself is unspeakable into more understandable form, since art must make the world of the spirit, the world of the invisible, the world of God graspable. Precisely music is capable of grasping various aspects of this message and transforming it into tones, cords, harmonies and melodies, which will stimulate the listener's intuition. ${ }^{12}$ Music can also be perceived as a kind of symbolic language. It is a voice which does not merely address the senses with sound, but grasps the mind and touches the heart. Unlike spoken word, music is a universal language. ${ }^{13}$

\footnotetext{
6 Ulrich MICHELS, Encyklopedický atlas hudby, Praha: Nakladatelství Lidové noviny, 2000, p. 11.

7 In a simplified way we can divide music and singing into the following four spheres, from which its functions are derived: 1. the sphere of the aesthetic effect of music - it is based on experiencing the feeling of "beauty", it is an individual matter dependent on individual taste, on the preference of certain musical genres and styles, where the artistic value of the composition need not be equal to the aesthetic value (e.g. even music rendered by amateurs can induce aesthetic experience in some listeners, even though the artistic value will not be high, and vice versa); 2 . the sphere of the therapeutic effect of music - besides music therapy etc. this comprises going to concerts in order to relax; 3. the sphere of the educational effect of music; 4 . the sphere of the ritual effect of music - besides cultic or liturgical music this includes profane music (graduation ceremonies, civil weddings), as well as going to techno parties etc.

8 Already the natural religions used music to influence the deities. Israelites turn to God by means of music and singing in praise, proclaiming his deeds and asking for blessing. Music is conceived as an appropriate means of response of the human being addressed by Divine communication. Since antiquity Christians have invoked and celebrated God by means of music. In the course of time liturgical music became a significant means in the dialogue with God. Further see František KUNETKA, Stručné dějiny hudby a zpěvu v liturgii, Olomouc: Matice cyrilometodějská, 1999.

9 Cf. Peter Paul KASPAR, Musica sacra: Das grosse Buch der Kirchenmusik, Graz, Wien, Köln: Verlag Styria, 1999, p. 7.

10 Josef RATZINGER, Duch liturgie, Brno: Barrister \& Principal, 2006, p. 119.

11 Pastoral Constitution on the Church in the Modern World Gaudium et spes, art. 57 (on-line), at: http://www.vatican.va/archive/hist_ councils/ii_vatican_council/documents/vat-ii_cons_19651207_gaudium-et-spes_en.html, accessed July 18, 2014.

12 JOHN PAUL II, Letter to Artists (on-line), at: http://www.vatican.va/holy_father/john_paul_ii/letters/documents/hf_jp-ii_let_23041999_ artists_en.html, accessed July 18, 2014.
}

13 Cf. Richard VILADESAU, Theology and the Arts, Mahwah, New Jersey: Paulist Press, 2000, p. 38. 
Some musical communications (especially vocal music), thanks to a text set to music, carry an easily understandable, extra-musical content (meaning). A great number of deep song texts, as well as various compositions on the positive values of life and faith in God, can greatly contribute to musical productions. In certain genres the text (or other extra-musical components) can inform us of various topics, which are amplified by the musical treatment. But on the other hand, the text and its contribution to the music can seem indifferent. We can easily listen to vocal music in a foreign language we cannot understand, i.e., without understanding the cognitive information or meaning of the text, and yet such listening and perception of music can strongly affect and enrich us. Music unconnected to words is pure spirituality. ${ }^{14}$

Thomas Aquinas, while answering the objection that with singing a lack of understanding of the text can occur, says: "Even though some do not understand what is being sung, they nonetheless understand why the singing is taking place, namely to praise God. And that is enough to uplift a human being to piety."15

Many times biblical word has become music (or another kind of art), which represents an extensive chapter of faith and beauty in the history of culture. "But for all, those who believe and those who do not, works of art inspired by Scripture remain a reflection of the impenetrable mystery, which enfolds and fills the world." 16 "There is a number of people who themselves can sing better with their hearts than with their mouths, but the singing of those, to whom it is granted with their mouths as well, can really make their heart sing, as if they themselves were singing in the others, and grateful hearing together with the singing of singers become a single act of praising God."17

\section{Beauty, music, God}

In the history of aesthetics we can see that the problem of classifying beauty was solved in various ways. Most authors classified beauty based on the natural categories of beautiful things. They distinguished, more or less congruently but with some variation, between infinite beauty (God) and finite beauty (creatures), they divided finite beauty into non-material and material, material beauty into natural beauty and artistic beauty, etc. We encounter such division not only in antiquity and the Middle Ages, but also in modernity.

In the following text the word beauty is not construed as a term denoting what satisfies the senses ("sensual beauty"), but as a term which could be expressed as beauty surpassing the senses. Aestheticism, which views art as an end in itself with its own criteria, is incompatible with the biblical model, which requires certain subservience of art. ${ }^{18}$

In discovering and accepting God the path of beauty is of eminent importance, since beauty is part of God's deepest nature. That is why God imprinted in human beings the ability to express even what is mysterious and incommunicable. We call it the gift of art, one of the seven gifts of the Holy Spirit. If we underestimated or neglected it, we would impoverish ourselves

\footnotetext{
14 Cf. Albert GERHARDS, Im Spannungsfeld von Wort und Zeichen, in: Musik im Raum der Kirche, Stuttgart: Carus-Verlag, 2007, pp. 52-55. 15 Josef RATZINGER, K teologickému základu liturgické hudby, Salve 2/2008, p. 21.

16 JOHN PAUL II, Letter to Artists.

17 Josef RATZINGER, K teologickému základu liturgické hudby, p. 22.

18 Cf. Josef RATZINGER, Bohu zpívejte umělecky (on-line), at: http://www.sdh.cz/sdh_htm/odjinud/zpivejte_um.htm, accessed July 14, 2014.
} 


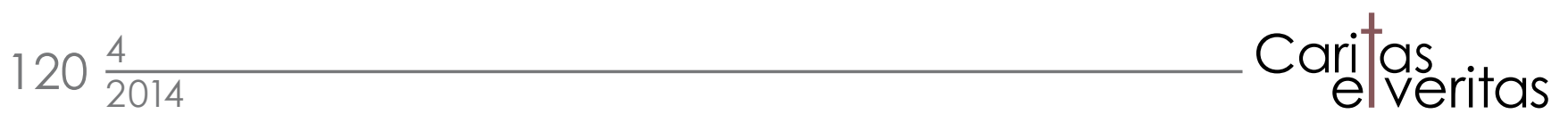

and our effort at evangelization would lack an important dimension, it would be poor and colourless. ${ }^{19}$

The relationship between the good and the beautiful can raise a number of stimulating considerations. In a certain sense beauty is a visible image of the good, just like the good is a condition of beauty. Throughout the Middle Ages the opposition between extrinsic and intrinsic beauty was a live issue, since imperishable intrinsic beauty is the only guarantee when facing the transitory character of extrinsic beauty. Mediaeval perception of beauty has many aspects. The mediaevals immediately turned the feeling for beauty into a feeling of communion with God. If beauty is to be a real value, it must correspond to the good, to truth and to all other attributes of being and divinity. It is further very difficult for a mediaeval person to view the value of beauty and utility separately. The scholasticism of 13th century established the concept of transcendental properties, i.e., the universal properties of being. According to traditional understanding the transcendentals are unum - the one, unity; verum - the true; bonum - the good, and others. There arose the problem whether beauty can also be viewed as a transcendental or not. If beauty were a permanent property of all being, then the beauty of the cosmos would not be grounded in a mere poetic feeling, but in metaphysical certainty. The problem of construing beauty as a transcendental brought the need to define the specific conditions on which being can be viewed as beautiful. Thus at one point philosophy began to feel the need for critically engaging the problem of aesthetics. Various opinions of beauty appeared as well as attempts to define it. E.g. William of Auvergne (French theologian and philosopher, $\uparrow$ ca. 1249) says that sensible beauty is "what is liked by the one who sees it", 20 intrinsic beauty is what arouses liking in the soul of the one who senses it and is willing to love it. The good found in the human soul is designated as beauty in analogy to extrinsic, visible beauty. Robert Grosseteste (English theologian and philosopher, $†$ 1253) defines beauty in terms of the good. "If it is common to all things that they tend toward the good and the beautiful, then the good and the beautiful are one and the same." ${ }^{21}$ According to him, the good is a divine name because it grants existence to things and conserves their being, while the beautiful is a divine name because it becomes the cause ordering the universe. ${ }^{22}$ Beauty is a transcendental even with St. Thomas. "Beauty and goodness in a thing are identical fundamentally; for they are based upon the same thing, namely, the form; and consequently goodness is praised as beauty. But they differ logically, for goodness properly relates to the appetite (goodness being what all things desire); and therefore it has the aspect of an end (the appetite being a kind of movement towards a thing). On the other hand, beauty relates to the cognitive faculty; for beautiful things are those which please when seen." ${ }^{23}$ And elsewhere: "The beautiful is the same as the good, and they differ in aspect only. For since good is what all seek, the notion of good is that which calms the desire; while the notion of the beautiful is that which calms the desire, by being seen or known. Consequently those senses chiefly regard the beautiful, which are the most cognitive, viz. sight and hearing, as ministering to reason; for we speak of beautiful sights and beautiful sounds. But in reference to the other objects of the other senses, we do not use the expression 'beautiful', for we do not speak of beautiful tastes, and beautiful odours. Thus it is evident that beauty adds to goodness a relation to the cognitive faculty: so that 'good' means that which simply pleases the appetite; while the 'beautiful' is something pleasant to apprehend." 24

19 Cf. Josef HRDLIČKA, Rozhlasové pořady o duchovní hudbě na Radiu Proglas.

20 Umberto ECO, Umění a krása ve středověké estetice, Praha: Argo, 1998, p. 41.

21 Ibid., p. 42.

22 Cf. ibid., pp. 35-45.

23 Thomas AQUINAS, Summa Theologica I, q. 5, a. 4, ad 1 (on line), at: http://www.newadvent.org/summa/1005.htm\#article4, accessed October 28, 2014.

24 Cf. ibid., I-II, q. 27, a. 1, ad 3. 
Beauty is the last word that a thinking intellect can afford to pronounce, since thereby she crowns inconceivable splendour, the double star of truth and the good and their indivisible relationship..$^{25}$ In connection with Beauty it is worthwhile to mention selected ways of addressing God in Jesus Christ. "You are beauty... You are beauty!" - this is how God is addresses by St. Francis of Assisi in his praise upon receiving Christ's stigmata. St. Bonaventure comments on this with the words: "In beautiful things I have contemplated the Most Beautiful One and following the imprints in creatures I have everywhere found the Beloved." ${ }^{26}$ In Eastern spirituality Christ is called "the most beautiful of all mortals" ${ }^{27}$ St. Augustin as a man in love with beauty says: "Late have I loved you, O Beauty ever ancient ever new, late have I loved you!" 28

Not only the abovementioned saints, but every human being getting to know the world notices its beauty. Scripture clearly says that the originator of beauty is God. In the Book of Wisdom we read: "What folly it argues in man's nature, this ignorance of God! So much good seen, and he, who is existent Good, not known! Should they not learn to recognise the Artificer by the contemplation of his works? Instead, they have pointed us to fire, or wind, or to the nimble air, wheeling stars, or tempestuous waves, or sun and moon, and made gods of them, to rule the world! Perhaps the beauty of such things bewitched them into mistaking it for divinity? Ay, but what of him who is Master of them all; what excellence must be his, the Author of all beauty that could make them!" (Wis 13:1-3) Beneficial to considering beauty as a path leading to God are the ideas of John Paul II expressed in his Letter to Artists. For him, as for the authors of biblical books, it is a matter of fact that beauty comes from God and man discovers it and imitates in his works, where a special role consists in the work of artists. "Beauty is a key to the mystery and a call to transcendence. It is an invitation to savour life and to dream of the future. That is why the beauty of created things can never fully satisfy. It stirs that hidden nostalgia for God..." 29 The path of beauty and art is one of the possible paths to the human soul - but in no way a commonplace and universally accessible one. It is demanding in disclosing beauty and in the formation which makes it possible to understand the message of beauty.

Already Pope John Paul II as well as his successors Benedict XVI and Pope Francis speak of the path of beauty as one of the possible paths leading to God and its possible use in proclaiming the gospel. Via pulchritudinis (The Path of Beauty) is also the title of the final document of the plenary assembly of the Pontifical Council for Culture of 2006. As the title shows, the document deals with the path of beauty as a suitable path of evangelization and dialogue. It perceives via pulchritudinis as a mediator of our via crucis, which is transformed in Christ into his via lucis. A work of art is not "beauty" in itself; it is an expression of the ineffable mystery of God. Beauty is therefore perceived as something that transcends aesthetic perception and leads to finding the embodiment of God. Works of art inspired by the Christian faith (musical composition, paintings, architecture, etc.) can, if appropriately used, make possible an encounter with God in the experience of faith. That is why it is desirable to guide people to understand the language of beauty, so that they can understand the message of Christian art. ${ }^{30}$

In the context of the present text's topic we will in the following part deal with the aesthetic aspect of music and its aesthetic effect from the point of view of the listener or concert-goer.

\footnotetext{
25 Cf. Hans Urs von BALTHASAR, Herrlichkeit, Eine thelologische Ästhetik, Frankfurt: Johannes Vlg., 1988, pp. 4-15.

26 Cf. JOHN PAUL II, Letter to Artists.

27 Cf. ibid.

28 Cf. ibid.

29 Ibid.

30 Cf. The Via Pulchritudinis, concluding document of the plenary assembly (on-line), at: http://www.vatican.va/roman_curia/pontifical_ councils/cultr/documents/rc_pc_cultr_doc_20060327_plenary-assembly_final-document_en.html, accessed October 28, 2014.
} 
This issue will also be viewed with respect to the above theses with an effort to show listening to music and understanding it as a form of via pulchritudinis. Many other important aspects that may be linked to the aesthetic function of music will be left aside (e.g. the performer, the composer, space, etc.). In what follows we will be interested in listening to music in various contexts and the ability to listen (to music). It is precisely the ability to listen and understand the musical communication what allows for the mediation of that beautiful, ungraspable, incommunicable message of music which may orient a perceptive listener to God.

Perceiving music and relationship to musical production can also be viewed from the aesthetic point of view. ${ }^{31}$ We can speak of aesthetic appropriation of music. We understand the term appropriation in this case as active oral reception (apperception) of the sound-musical surroundings of the human being as well as creating a new artificial musical environment capable of carrying aesthetic and practical functions. Aesthetic appropriation of music occurs in the process of perceiving music in historic and social context, as well as in an individual one. This appropriation has both a creative, compositional form, and a listener's form. Listening appropriation is designated as reception of music $\left(\mathrm{Z}\right.$. Lisa) ${ }^{32}$ or as musical apperception (I. Poledňák). ${ }^{33}$ It is a highly active process. We can point out a certain analogy between active listening to music and the requirement of active participation in celebrating liturgy, as stated in Sacrosanctum Concilium as one of further forms of celebrating liturgy: "And at the proper times all should observe a reverent silence." ${ }^{34}$ Active participation here does not mean merely the external expressions of individuals, but precisely listening, perception, receiving with the senses and the spirit. Thus a person listening to the musical message, addressed by the music, must make a certain effort, be active, although she does not express herself externally in any way. Without sensitive hearing and a ready mind listeners would not hear even the most beautiful music as "beautiful". ${ }^{35}$

When we consider the issue of "musical values" in a musical-aesthetic way, we can state that musical values are relative, they can be valid only within a certain era, a certain type or stratum of society. Even though musical formations are transferrable in time and space, they need not be necessarily transferrable also in the value-related sense, i.e., as works with an artistic or aesthetic effect. Music is the product of a society which shares historically changeable musical value criteria. The gnoseology of music, as one of the fields of investigating music, deals with the historically changeable human possibilities to know and understand music, or with the help of music to know and understand something beyond itself. ${ }^{36}$

When someone is inclined to perceiving music - is able to decode and interpret the artistic communication - it need not necessarily mean that she can understand a work of art. To understand "something" means to be familiar with the thing, to be able to find one's way around it. But the measure of understanding is not determined by the amount of the understood, ${ }^{37}$ but by substantial significance. Substantially significant is not whether the individual concerned

31 Musical aestheticism is a sounding tertiary property of beauty or other impressiveness (perfection, nobility, agreeability...) ascribed to music, which invokes a feeling of pleasure in the listener leading to the demand for repeated inducement of such pleasure. In the case of author (composer) such pleasure induces the feeling of creative satisfaction.

32 Cf. Jan VIČAR - Roman DYKAST, Hudební estetika, Praha: AMU, 2002, p. 28.

33 Cf. ibid., p. 28.

34 Constitution on the Sacred Liturgy Sacrosanctum Concilium, art. 30 (on-line), at: http://www.vatican.va/archive/hist_councils/ii_vatican_ council/documents/vat-ii_const_19631204_sacrosanctum-concilium_en.html, accessed June 18, 2014.

35 Cf. Jan VIČAR - Roman DYKAST, Hudební estetika, pp. 27-29.

36 Cf. ibid., pp. 29-34.

37 E.g. if I know that the tones I hear are C1, E1 and G1, my understanding is simpler than if I can be aware of hearing the intervals of major and minor third. My understanding will be even deeper if I realize that these intervals constitute a major triad and when I perceive these tones in context as the tonic chord of $\mathrm{C}$ major. 
with music (listener, performer) understands a language, a sign system (knows the notation system) and based on that can appropriately react to the directions of another user of the language, system - she can play, read the composition from score. The fact that she understands a given language does not mean that she can understand the meaning of the communication. Essential for understanding (decoding) and grasping a work of art (a musical composition) is "seeing" inside the thing, knowing why the work of art came to be, understand a particular work differently - I would play, perform it differently, to project one's own feelings and experiences in the work. ${ }^{38}$ Only when we have understood the meaning of the musical communication can we "effectively" aesthetically experience it. If that is not the case, we listen but do not hear.

In this context one other aspect needs to be mentioned which plays a very important part in understanding an artistic communication (music) and spiritual phenomena, namely feeling. Spiritual phenomena (including art) cannot be fully grasped by reason alone, they must also be experienced. ${ }^{39}$ "By bringing in his own mood, the listener can view music aesthetically as a work of art, or as the musical rendering of an idea, or just perceive it and let the "waves" of tones affect him. He can grasp deeply something that the author only felt superficially, he can seek ideas where there are none, or find weak much that conceals deep feeling." ${ }^{40}$

Both rational and aesthetic understanding of a musical work can be markedly aided by knowledge of musical history, musical theory, the context in which a particular work came to be, as well as by a certain "readiness" of the listener ("involved listener"). A fairly extensive group of music "consumers" (whether those who attend concerts of various genres or those who listen to music by means of various technical equipment and music carriers) consists of persons with no musical education or no "preparation" for listening to music. And yet even in such situations music can touch the individual, address her, catch her interest and talk to her. "Perhaps it is sometimes better to know nothing at all about music, than have the half-knowledge that snobs brim over with." ${ }^{41}$ Besides the above mentioned ways of perceiving music and musical effectiveness, we can work with yet another possibility - so-called prepared spontaneity. According to this theory one cannot approach listening to music with no preparation at all (certain psychological preparation would be sufficient), but these preparatory phases need not necessarily disturb the immediacy of the contact with music.

In active listening the listener assesses the previous course of the musical composition and anticipates its further course, restructures and aesthetically interprets it. She is limited and influenced by her musical knowledge, experience and needs. Evidently, the assessment and feeling of an individual when a particular piece has ended will be highly individual. On the other hand, it is possible that this perception will be similar or same as that of other listeners. When perceiving music a listener has much that is individual, that characterizes her alone, as well as much that is shared with other listeners. "All this together creates the specific mixture of a shared experience of beauty in the thousands of its individual specifications, which occurs in similarly musically sensitive and informed public concert goers and imprints on these productions an unrepeatable atmosphere of individuality." ${ }^{42}$

\footnotetext{
38 Cf. Jiří KULKA, Psychologie umění, Praha: Grada Publishing, a. s., 2008, pp. 358-372.

39 Cf. ibid., pp. 370-371.

40 Friedrich NIETZSCHE, Rané texty o hudbě a řeči, Praha: OIKOYMENH, 2011, p. 122.

41 Ernst Hans GOMBRICH, Př́běh umění, Praha: Argo, 1999, p. 29.

42 Jan VIČAR - Roman DYKAST, Hudebni estetika, p. 64.
} 


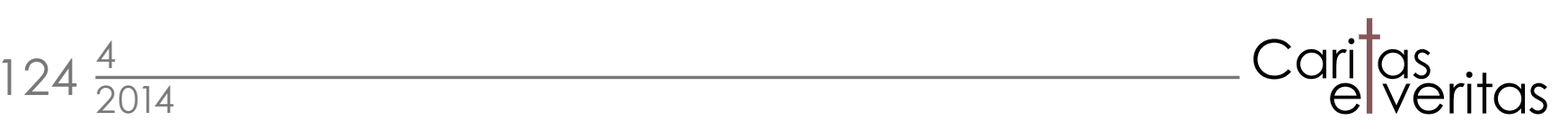

\section{Pre-evangelization}

For the purposes of the following text let us leave aside discussion over the question whether proclaiming the Gospel needs some form of pre-evangelization at all. Let us hold on to the explanation of this concept as described in the apostolic exhortation of Paul VI (1975).$^{43}$ This understanding was also adopted by the Plenary Council of the Catholic Church in CR (2005). ${ }^{44}$ Pre-evangelization (i.e., preliminary evangelization) is the first and initial evangelization conducted by the Church. But even this pre-evangelization is already in fact evangelization, though merely in an initial and as yet incomplete measure. An almost infinite number of various means is used in pre-evangelization, among which preaching certainly has a place, but also art, ethical education, academic preparation, philosophical research and justified action on the emotions of the human heart. Although this initial proclamation of the Gospel is especially intended for those who had never heard of Christ's good news (or children), it is evident that this manner is necessary because the contemporary world is often de-Christianized - there are many people who have been baptized but do not live in a Christian way. ${ }^{45}$ Pre-evangelization therefore begins with an offer of spheres of general human interest, common to believers and non-believers, and further the willingness to be with them and prepare the ground for the good news in their language.

In the context of the preceding text we can also understand the term pre-evangelization as the development of natural, cultural and moral values in society. Pre-evangelization creates space which makes it possible to evangelize. It also means sustaining a positive attitude to moral values important for the society and overcoming prejudice with respect to the Church.

In his apostolic exhortation Evangelii gaudium (2013) ${ }^{46}$ focusing on preaching the Gospel in the contemporary world, Pope Francis points out the "path of beauty" (via pulchritudinis) ${ }^{47}$ and artistic expression in proclaiming the Gospel. He designates these forms as the new language of parables.

According to this text, to proclaim Christ means to show that believing in him and following him is not only something true and right, but also beautiful, capable of giving new shine to life and deep joy even among trials. In this perspective all expressions of authentic beauty can be recognized as a path facilitating an encounter with the Lord Jesus. It is not aesthetic relativism that can obscure the indivisible bond between truth, the good and beauty, ${ }^{48}$ but a renewal of respect for beauty with the aim of reaching the human heart and letting the truth and goodness of the Resurrected one shine out in it. If it is as St. Augustine says, that we love only that which is beautiful, then the Son made human - a revelation of infinite beauty - is supremely worthy of love and draws us to himself with a bond of love. It is therefore necessary that a part of

43 Cf. PAUL VI, Evangelii nuntiandi, art. 51, 52.

44 Cf. Život a poslání krestanů v Církvi a ve světě (Závěrečný dokument Plenárního sněmu katolické církve v ČR), Kostelní Vydří, 2007, p. 114.

45 Cf. PAUL VI, Evangelii nuntiandi, art. 51, 52.

46 Cf. FRANCIS, Evangelii gaudium, Praha: Paulínky, 2014.

47 The path of beauty (via pulchritudinis) - that it how in his addresses Benedict XVI calls the path (form) capable of leading the mind and the heart to eternity, lift them up to Divine heights. The path of beauty is at the same time an artistic, aesthetic approach and a path of faith and theological quest. The path of beauty leads to comprehending the Whole in a fraction, the Infinite in that which is finite, God in the history of humanity.

48 Benedict XVI makes a similar appeal in his address to artists: "The quest for beauty that I am describing here is clearly not about escaping into the irrational or into mere aestheticism. Too often, though, the beauty that is thrust upon us is illusory and deceitful, superficial and blinding, leaving the onlooker dazed; instead of bringing him out of himself and opening him up to horizons of true freedom as it draws him aloft, it imprisons him within himself and further enslaves him, depriving him of hope and joy. It is a seductive but hypocritical beauty that rekindles desire, the will to power, to possess, and to dominate others...", BENEDICT XVI, address to artists "You are the Custodians of Beauty" (on-line), at: http:/ / www.zenit.org/en/articles/benedict-xvi-s-address-to-artists, accessed November 16, 2014. 
transmitting faith be formation deriving from via pulchritudinis. It is desirable that every local church in its evangelizing action support the use of art in a link to the treasures of the past, but also in the breadth of its various contemporary expressions, so that faith is again transmitted in a new "language of parables" ${ }^{49}$ Courage is needed to find new signs, new symbols, a new body for transmitting the Word, various forms of beauty appearing in various cultural environments, including the non-conventional modalities of beauty which can be of little significance for those proclaiming the Gospel, but have become particularly attractive for others. ${ }^{50}$

In his address to the participants in the International Congress of Sacred Music John Paul II sketches one of the possibilities of using (religious) music in the (pre-)evangelization effort: "Religious music likewise builds bridges between the message of salvation and those who, while not yet fully accepting Christ, are sensitive to beauty, for beauty is a key to the mystery and a call to transcendence. Beauty makes a fruitful dialogue possible." 51

In making use of new catechumenal paths, music offers opportunities of free creative encounter in the "front hall" of the Christian community and proclaiming the Gospel. Music, primarily spiritual, can be perceived as one of the means through which we can be addressed by the word of God. ${ }^{52}$

When seeking an answer to the question how to introduce the society (children, young people and adults) to Jesus Christ in such a way that they get to know his person and his mission and are directed towards him, it is necessary to note the contemporary society's means of expression and communication. Due to the great development of various technical means, many people at present are in the habit of surrounding themselves with music almost incessantly. As a result of this excess of music verging on a sort of "musical smog", human beings may lose the type of musical-aesthetic perceptiveness they used to have. The easy availability of music by means of mass media leads to a certain devaluation of artistic values and in some strata of society music is becoming a means of disengaging from the external world, a sound screen, a "drug". It is therefore desirable to consider and recommend suitable performers, composers and options of listening to music (taking part in concerts etc.). It is not just a matter of emphasizing music that would engage the listener in some way, but of pointing out music whose authors express their relationship to God through it. ${ }^{53}$

Based on the preceding text we can state that such music can become a "pulpit" through which the Church can speak to people. Martin Luther even called religious music "resonant preaching". However, he is not dealing with music as carrier of text, but as a reflection of Divine beauty. Music, according to him, can address the soul with information on God in situations when it is impossible to express it with words. ${ }^{54}$ Through music inspired by the Christian faith "we perceive beauty in a marvellous way, which enables us to experience the Divine presence sometimes more effectively than preaching. Music linked to catechesis proclaims beauty, tran-

\footnotetext{
49 Some translations use the term: "new "parabolic language'". The term refers to an address by Benedict XVI delivered at the projection of the film document "Arte e fede - via pulchritudinis". The language of art is a linguistic parable (or perhaps better - a reference to the arch of the high vault of the original "parabola"), characterized by general accessibility.

50 Cf. FRANCIS, Evangelii gaudium, art. 167.

51 JOHN PAUL II, Address to the Participants in the International Congress of Sacred Music (on-line), at: http://www.vatican.va/holy_father/ john_paul_ii/speeches/2001/documents/hf_jp-ii_spe_20010127_religious-music_en.html, accessed October 28, 2014.

52 Cf. Maeve Louise HEANEY, Music as Theology, Eugene, Or.: Wipf and Stock Publishers, 2012, pp. 130-135.

53 We are not concerned with "merely" liturgical music - i.e., music which is used to accompany the liturgy or becomes part of liturgy. We mean music inspired by religion - by reverence for God and the saints, by the Bible, liturgy and life of the Church. It comprises both artificial music and non-artificial one.

54 Cf. Richard VILADESAU, Theology and the Arts, p. 34.
} 


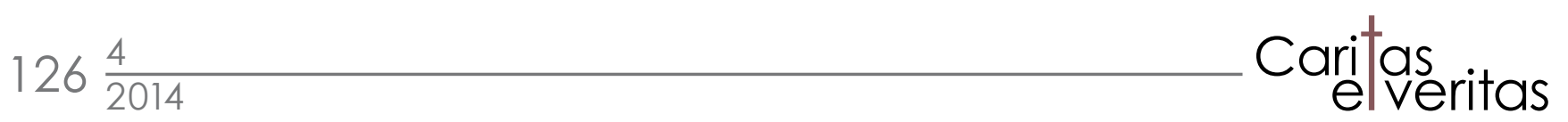

scendental beauty, which transcends the boundaries of reason and experience and therefore cannot be anything but intrinsic beauty. Thus God manifests himself in his splendour and glory and points to the invisible, just as the Son visibly points to the invisible Father." ${ }^{55}$ In this sense we can even consider a certain missionary function of music. Attention to liturgical music in the missionary task is witnessed by a text in the constitution Sacrosanctum Concilium. "In certain parts of the world, especially mission lands, there are peoples who have their own musical traditions, and these play a great part in their religious and social life. For this reason due importance is to be attached to their music, and a suitable place is to be given to it, not only in forming their attitude toward religion, but also in adapting worship to their native genius..." 56

The fact that the Church was and still is aware of the significance and importance of music, not only in liturgical ceremonies, is evinced by a long number of decrees and documents dealing with music, especially liturgical one. From the very beginning, emphasis was laid on the urgent task of serving the neighbour, of educating the faithful in the sense of St. Paul's letters (Col 3:16): "Let the word of Christ dwell in you richly, teaching and admonishing one another in all wisdom, singing psalms and hymns and spiritual songs, with thankfulness in your hearts to God..." To this demand corresponds the text of Pope Pius X: "Sacred music as an integral part of festive liturgy shares its general goal, which is the glory of God and sanctification and education of the faithful..." ${ }^{57}$ In the oldest preserved decree on church music proclaimed by Pope St. Gregory the Great (595) we read: "The cantor must sing with a good opinion, if he wants to educate the people." ${ }^{58}$ Most Church decrees and documents on music deal with the relationship of music and liturgy. In these texts church music is understood primarily in the narrow sense of the word - as liturgical music with which liturgy is conducted (mass, daily prayer of the Church, sacraments and sacramentals). These are texts set to music, folk spiritual songs and their instrumental accompaniments, preludes, interludes and postludes: "that which, being created for the celebration of divine worship, is endowed with a certain holy sincerity of form." ${ }^{59}$ To understand the issue it would be necessary to describe and think through further causes, contexts and motifs, which is beyond the topic scope of this paper. For the sake of basic orientation the footnote gives a simplified overview of Church documents and texts dealing with liturgical music. ${ }^{60}$

\section{Conclusion}

The development of European music is linked to Christianity. This happens both at the level of content and themes and at the theoretical level. Music filled with Christian ideas can sometimes affect the mind and emotions more than verbal expressions. ${ }^{61}$ Works of music inspired by Christianity are an exceptional part of the musical and cultural heritage.

\footnotetext{
55 Pavel ŠUPOL, Křest'an a hudba, Brno: Kartuziánské nakladatelství, 2010, p. 54.

56 SC 119.

57 Cf. PIUS X., Motu proprio "Tra le sollecitudini" (on-line), at: http://www.sdh.cz/sdh_htm/archiv/mo_pro.htm, accessed November 28, 2014.

58 Peter Paul KASPAR, Musica sacra: Das grosse Buch der Kirchenmusik, p. 35.

59 Instruction on Music in the Liturgy Musicam Sacram, art. 4 (on-line), at: http://www.vatican.va/archive/hist_councils/ii_vatican_council/ documents/vat-ii_instr_19670305_musicam-sacram_en.html, accessed October 28, 2014.

60 Basic norms of the Catholic Church concerning liturgical music since the beginning of the 20th century: motu proprio of Pius X "Tra le sollecitudini" concerning sacred music (1903); apostolic constitution of Pius XI "Divini cultus sanctitatem" (1928); encyclical of Pius XII "Musicae sacrae disciplina" (1955); instruction on church music and sacred liturgy (1958); SC, chapter 6 "De musica sacra" (1963); instruction "Musicam Sacram" (1967); General Instructions of the Roman Missal (1970); instruction on implementing liturgical norms "Inter Oecumenici" (1964), “Tres abhinc annos" (1967), “Liturgicae instaurationes" (1970).

61 Cf. Ferdinand KLINDA, Křest́anstvo a hudba na Slovensku, Kultúra 18/2003, p. 15.
} 
Such musical communications as we have described above can open up and broaden the horizons of human consciousness and point beyond them. The aesthetic effect of music is based on individual experience of the feeling of beauty. It is the sounding property of beauty ascribed to music.

That is why we focused further on the sphere of beauty and dealt with the beautiful in the context of the topic. We confronted the beautiful and the good and based on the theses presented can state that beauty is in a certain sense a visible image of the good, just as the good is a condition of beauty. We speak of beauty, which originates from God and awakens that mysterious desire for God, in connection with the path of beauty (via pulchritudinis). This path of beauty can offer one possibility of (pre-)evangelization.

We also mentioned the ability to listen to music and understand it. It is an important condition of listening musical activities. Learning to listen to a musical communication also means leading the listener to perceive silence. The relationship of music and silence does not consist only in the opposition claiming: Silence is the absence of music. On the contrary, thanks to the ability to listen to silence we can perceive the individual tones which emerge out of the silence and return to it again. For perceiving and listening to music the experience of listening is important and silence can be the key to experience with sound.

Although the extent of the paper and its definition in the introduction does not allow for introducing particular practical examples, which would be interestingly supplement the ideas presented, we will briefly introduce one illustrative example.

\section{Gregorian chant}

It is a liturgical, Latin, monophonic chant without instrumental accompaniment. ${ }^{62}$ The Catholic Church has always considered this chant to be its own and taken it as a model and ideal of liturgical music. For broad masses of contemporary people Gregorian chant is becoming an interesting listening musical alternative. Besides authentic singing Gregorian chant is becoming (as it has been throughout the centuries of its existence) an inspiration for contemporary musical language, both in the sphere of artificial music and in the non-artificial one. Musicological disciplines ascribe this success to the fact that it is a simple, melismatic chant without regular rhythmical segmentation and beyond the tonality of major and minor (the chant uses so-called Church modes). To put it in a simplified manner: The chant offers the listener a totally different type of music than she is used to from the radio, TV..., which makes her listen to this music and perceive it differently. An uninformed listener need not know that it is a liturgical chant, a text expressing various aspects of religious and liturgical life and relationship to God. And yet there is an idea rooted in humanity that the chant is linked to temple, monasticism, the Church, to mysticism, etc. The chant, besides its ritual function (as liturgical music), can also fulfil an aesthetic function (concert performance), it has an educational function (as an academic subject - examining the compositional technique and religious life of a particular period) and can also have a therapeutic function in psycho-hygiene (listening and relaxation at home) etc. All these aspects and other symbols can be used and with the help of intersections of the individual spheres it is possible to work with them in concerts, musical shows or creation of musical recordings. Although the mission of the chant was never understood by the Church as mere aesthetic setting of words to music or creating relaxation pieces for therapeutic purposes, it can be that "non-conventional modality of beauty" of which Pope Francis speaks, which has little significance for those who proclaim the Gospel but can be especially attractive for others. We 


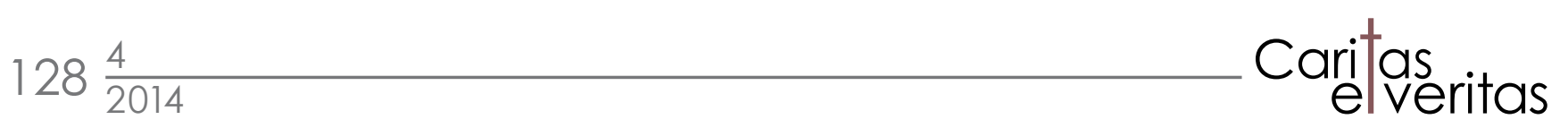

can also understand his words to mean that it is not necessary to use what is established, build only on matters of the past (liturgically understood chant), but that there are positive realities that have not yet been put to use (commented concert of Gregorian chant, samples of pieces inspired by the chant...).

Despite the music of the Renaissance, the Baroque and great polyphony, Gregorian chant lives out of the inner wealth of a synthesis of spirit, intuition and sensible sound even in the fullness of these possibilities. The "greatness" and depth of this music is linked to the possibility of growing out of an anthropological foundation where the spiritual and the profane conjoined into a human unity. Music able to fulfil the exhortation "Lift up your hearts" must in some way integrate the senses into the spirit, but cannot be "only" pure spiritualization. It ought to be such connection of the senses and the spirit in which both becomes personality. If only sensual pleasure was at work in a musical production, which cannot be increased infinitely, disappointment would result after some time. And precisely thanks to integration in the spirit, the senses receive new depth and can reach into spiritual infinity. Music thus conceived cleanses the human being and lifts her up. ${ }^{63}$

In order for music to be considered as an aspect of pre-evangelization, it should not be understood merely as a means of the self-realization and exhibition of some artists. Such music loses the ability to vibrate the strings of our hearts, broaden our souls, and thus convert them to God more easily.

According to Joseph Ratzinger the greatness of this music consists in that it is the most immediate and most convincing verification of the Christian faith in salvation that history offers us. When one has been captivated by such music, she already knows in her heart that faith is true, although she still needs to take many steps in order to fortify this feeling with reason and will.

\section{Music as a Possible Aspect of Pre-Evangelization}

Abstract The paper deals with the relationship of music and religion. The text describes the aesthetic function of music and its theological-philosophical foundation. In the selected sphere the paper points out the use of listening to music as a form of pre-evangelization. The topic is discussed in the context of Church documents and corresponds to the perception and function of music in the Church.

Keywords music; aesthetics; pre-evangelization

63 Cf. Josef RATZINGER, Světský a lidský obraz a jeho odraz v liturgické hudbě, Bonum, Verum, Pulchrum, vol. II., 2, 3, 4/2009 (on-line), at: https://sites.google.com/site/bovepul/archiv/roc-ii-c-2-3-4-2009/svetsky-a-lidsky-obraz-a-jeho-odraz-v-liturgicke-hudbe, accessed August 22, 2014. 